\title{
RESPONSE OF TWO POTATO VARIETIES TO IRRIGATION METHODS IN THE DRY MEDITERRANEAN AREA
}

\author{
IBRAHIM MUBARAK*, MUSSADDAK JANAT, MOHSEN MAKHLOUF
}

\author{
Department of Agriculture, Atomic Energy Commission of Syria
}

MUBARAK, I. - JANAT, M. - MAKHLOUF, M.: Response of two potato varieties to irrigation methods in the dry Mediterranean area. Agriculture (Pol’nohospodárstvo), vol. 64, 2018, no. 2, pp. 57-64.

\begin{abstract}
Due to water scarcity and dry Mediterranean conditions, improving water use efficiency is a major challenge for sustainable crop production and environment protection. Field experiments were conducted for two consecutive years (2010 and 2011) to assess the effects of variety and irrigation method on potato crop, following a $2 \times 4$ factorial experiment type arranged in a split plot design with two spring potato varieties (Spunta and Marfona), and four irrigation methods (drip irrigation with two modes of dripper spacing/dripper flow: $30 \mathrm{~cm}$ at $41 / \mathrm{h}$ and $60 \mathrm{~cm}$ at $81 / \mathrm{h}$, sprinkle irrigation, and furrow irrigation), with three replicates. Potato was irrigated when soil moisture in the active root depth was within the range of $75-80 \%$ of field capacity as determined by the neutron probe technique. Results did not show any differences between both varieties. Moreover, no differences in marketable yield, total dry matter, and harvest index were found between irrigation methods. However, results showed that sprinkle irrigation significantly enhanced nitrogen use efficiency. Furthermore, both water productivity and irrigation water use efficiency were significantly increased under drip irrigation compared with the other irrigation methods. They were about twice those under furrow irrigation, indicating that the employment of drip irrigation method can effectively address water shortage and sustainable potato production, in the dry Mediterranean region.
\end{abstract}

Key words: drip irrigation, sprinkle irrigation, water productivity, irrigation water use efficiency, ${ }^{15} \mathrm{~N}$, nitrogen use efficiency

Potato (Solanum tuberosum L.) is one of the most economical crops grown worldwide, with a total production of about 365 million ton (FAOSTAT 2014). It is a shallow-rooted crop and more sensitive to soil water stress than other deeper-roots crops. Its water requirements vary with locations, agricultural practices, and soil types. In regions where water resources are scarce, as in the dry Mediterranean region, efficient water use is an urgent need to meet a sustainable crop production for substantial food demands. Moreover, higher benefits may be acquired by adapting suitable irrigation techniques (Ati et al. 2012; Badr et al. 2012; Eskandari et al. 2013; El-Mokh et al. 2015; Matovic et al. 2016).
Drip irrigation method proved useful in improving water and fertiliser use efficiencies, enhancing yield, reducing the environmental pollution risk, and its amenability to conform to irregularly shaped fields, compared with sprinkle and surface irrigation (Tiercelin 2007; Matovic et al. 2016). Similar studies have reported that drip irrigation is well suited for row crops such as potato production (Ati et al. 2012; Eskandari et al. 2013; Cantore et al. 2014; Matovic et al. 2016). Moreover, several studies have shown that although no significant differences in tuber yield were observed between furrow and drip irrigation methods, the drip irrigated potato consumed less water relative to the other irrigation

Ibrahim Mubarak, PhD. (*Corresponding author), Department of Agriculture, Atomic Energy Commission of Syria, P.O. Box 6091, Damascus, Syria. E-mail: ascientific@aec.org.sy

Mussaddak Janat, PhD., Department of Agriculture, Atomic Energy Commission of Syria, P.O. Box 6091, Damascus, Syria. E-mail: ascientific@aec.org.sy

Mohsen Makhlouf, M.Sc., Department of Agriculture, Atomic Energy Commission of Syria, P.O. Box 6091, Damascus, Syria. E-mail: ascientific@aec.org.sy 
methods, resulting in higher water use efficiency. The huge amount of water applied when using sprinkle and furrow irrigation methods combined with the need to apply nitrogen fertiliser at high rates may result in the lose of nitrate and other nutritive components to deep percolation (Ati et al. 2012; Onder et al. 2015).

Potato productionoccupies a veryimportant place in Syria, with more than 25,000 ha of planted area and an average marketable yield of about $19.7 \mathrm{t} / \mathrm{ha}$ for various potato varieties grown in different climatic conditions, soils, and cropping systems (Annual Agricultural Statistics 2011). Traditionally, sprinkle and furrow irrigation methods are the most common irrigation practices used in potato production in the Mediterranean cropping system. Generally, drip irrigation method is not widely adopted for potato production in Syria because of the high initial investment compared to other used irrigation methods. Currently, because of water scarcity, growers have been encouraged to adopt drip irrigation by Syrian government in order to enhance water productivity. Although the cost of its installation has relatively dropped recently, drip irrigation is still uncommon and its use has seen a moderate increase only.

In this context, the objective of the study reported herein was to assess the effects of various irrigation methods, including drip irrigation, on two potato varieties widely grown in Syria. The obtained results may encourage the introduction of alternative and more practical irrigation methods that would sustain potato productivity while using less water in the context of water savings and environmental protection.

\section{MATERIAL AND METHODS}

\section{Site description and field procedure}

Field experiments were conducted at Teezeen's Irrigation Research Station, near Hama, Syria $\left(35^{\circ} 48^{\prime} \mathrm{N}, 36^{\circ} 27^{\prime} \mathrm{E}\right)$, for two consecutive growing seasons 2010 and 2011. The area is characterized by the dry Mediterranean type climate. The total annual rainfall is about $350 \mathrm{~mm}$, on average. Some climatic data collected during the course of those experiments are shown in Table 1.
Representative soil samples were taken up to a depth of $90 \mathrm{~cm}$ in $15 \mathrm{~cm}$ increments prior to planting. The soil type is most likely Inceptisols (classified as Calcixerollic Xerochrept), had a clayey texture throughout the $90 \mathrm{~cm}$ soil profile. Some selected soil properties are shown in Table 2. The experimental field was conventionally prepared, i.e., disked, ploughed, and bedded into $0.75 \mathrm{~m}$ hills before planting. Two spring potato varieties Spunta and Marfona were planted on the $23^{\text {rd }}$ Feb and $11^{\text {th }}$ Feb of the year 2010 and 2011, respectively, spaced $0.75 \times 0.20 \mathrm{~m}$ apart, giving about 67,000 plants $/$ ha .

\section{Irrigation treatments}

The experiment was a split plot design with a $4 \times 2$ factorial type. Treatments consisted of four irrigation methods as main-plot treatments, and two spring potato varieties as subplot treatments, in three replicates.

The $1^{\text {st }}$ irrigation method was a set system of sprinkle irrigation, including 12 sprinklers spaced at $9 \times 12 \mathrm{~m}$, covering an experimental plot of $12 \times$ $60 \mathrm{~m}$. The $2^{\text {nd }}$ and $3^{\text {rd }}$ methods were two regimes of drip irrigation with two different modes of dripper spacing/dripper flow: the $1^{\text {st }}$ was with $30 \mathrm{~cm}$ at $41 / \mathrm{h}$ (Drip30) and the $2^{\text {nd }}$ with $60 \mathrm{~cm}$ at $81 / \mathrm{h}$ (Drip60). In both drip methods, amounts of irrigation water per unit area were identical. An experimental plot of $24 \times 60 \mathrm{~m}$ was used for drip-irrigated potato. Each crop row had its own dripline. The $4^{\text {th }}$ irrigation method was furrow irrigation, with an experimental plot of $9 \times 60 \mathrm{~m}$. A minimum spacing of $5.0 \mathrm{~m}$ was maintained between plots to minimize water intervention among treatments. Under each irrigation method conditions, the plot was further divided into six subplots (experimental units) for both potato varieties with three replicates. Each experimental unit was of $30 \times 3 \mathrm{~m}$ with four crop rows spaced $0.75 \mathrm{~m}$.

Soil water content (SWC) was observed using neutron probe technique. Access tubes were installed in the central row of each experimental unit. This technique enabled monitoring SWC status in the root zone and provided feedback data for irrigation scheduling. The active root depths, which were determined by soil moisture depletion curve generated by neutron probe feedback data, were $0.30 \mathrm{~m}$ during the period from planting until the middle of tuber initiation, and then reached up to $0.60 \mathrm{~m}$ until maturation, under both sprinkle and drip irrigation 
methods. However, under furrow irrigation method, active root depths were 0.45 and $0.75 \mathrm{~m}$ at both periods, respectively. These active root depths were used to calculated irrigation water amounts needed in each irrigation event. Water was applied when SWC in active root zone reached 75 to $80 \%$ of field capacity. A reduction factor due to the ground cover percentage was used under drip irrigation methods as 0.5 from planting until the flowering stage, and 0.75 until termination period. Volumes of water applied were monitored by flow meters.

\section{Fertiliser application}

In $2010,46.0 \mathrm{~kg}$ of $\mathrm{P}_{2} \mathrm{O}_{5} /$ ha as triple super phosphate (TSP), $48 \mathrm{~kg}$ of $\mathrm{K}_{2} \mathrm{O} / \mathrm{ha}$ as potassium sulphate, and $30.0 \mathrm{~kg}$ of $\mathrm{N} / \mathrm{ha}$ as urea $(20 \%$ of the total $\mathrm{N}$ amount) were broadcasted before planting according to the soil availability index for all experimental units under all irrigation methods. The remaining amount of $\mathrm{N}(120 \mathrm{~kg} \mathrm{~N} / \mathrm{ha})$ was applied in four equally split applications. In 2011, $78 \mathrm{~kg} \mathrm{P}_{2} \mathrm{O}_{5}$ /ha as TSP, $39 \mathrm{~kg} \mathrm{~K}_{2} \mathrm{O} / \mathrm{ha}$ as potassium sulphate, and $37 \mathrm{~kg}$ $\mathrm{N} /$ ha as urea ( $20 \%$ of the total $\mathrm{N}$ amount) were applied before planting. The remaining amount of $\mathrm{N}$ (142 kg N/ha) was added in three equally split applications. During the growing seasons, the added $\mathrm{N}$-fertilisers were either broadcasted for the sprinkle and furrow irrigated plots or injected through the drip method for the drip-fertigated plots.

$\mathrm{T}$ a

Climatic data of the experimental site during both studied growing seasons

\begin{tabular}{|c|l|r|r|r|r|r|}
\hline Year & \multicolumn{1}{|c|}{ Variable } & February & March & April & May & June \\
\hline \multirow{5}{*}{2010} & $\mathrm{~T}_{\text {max }}\left[{ }^{\circ} \mathrm{C}\right]$ & 14.1 & 18.0 & 22.9 & 28.6 & 33.1 \\
& $\mathrm{~T}_{\text {min }}\left[{ }^{\circ} \mathrm{C}\right]$ & 8.6 & 9.6 & 12.9 & 17.6 & 22.6 \\
& $\mathrm{~T}_{\text {average }}\left[{ }^{\circ} \mathrm{C}\right]$ & 13.1 & 15.7 & 20.3 & 25.9 & 30.0 \\
& $\mathrm{RH}[\%]$ & 82.0 & 73.0 & 59.3 & 50.0 & 47.0 \\
& Bright sunshine $[\mathrm{h}]$ & 4.3 & 6.7 & 9.4 & 11.3 & 12.6 \\
& Rainfall $[\mathrm{mm}]$ & 30.5 & 8.8 & 2.4 & 0.0 & 0.0 \\
\hline \multirow{5}{*}{2011} & $\mathrm{~T}_{\text {max }}\left[{ }^{\circ} \mathrm{C}\right]$ & 14.2 & 16.0 & 20.2 & 25.6 & 31.8 \\
& $\mathrm{~T}_{\text {min }}\left[{ }^{\circ} \mathrm{C}\right]$ & 8.5 & 7.6 & 12.4 & 16.0 & 22.0 \\
& $\mathrm{~T}_{\text {average }}\left[{ }^{\circ} \mathrm{C}\right]$ & 12.6 & 13.9 & 18.0 & 23.1 & 29.3 \\
& $\mathrm{RH}[\%]$ & 81.0 & 75.0 & 68.7 & 61.3 & 48.0 \\
& Bright sunshine $[\mathrm{h}]$ & 5.5 & 7.9 & 7.8 & 10.0 & 12.1 \\
& Rainfall $[\mathrm{mm}]$ & 42.7 & 55.3 & 26.1 & 14.8 & 0.0 \\
\hline
\end{tabular}

$\mathrm{T}_{\max }$ - maximum temperature; $\mathrm{T}_{\min }-$ minimum temperature; $\mathrm{T}_{\text {average }}$ - average temperature; $\mathrm{RH}$ - relative air humidity

$\mathrm{T}$ a

Selected chemical and physical properties of soil at the experimental site

\begin{tabular}{|c|c|c|c|c|c|c|}
\hline $\begin{array}{c}\text { Depth } \\
{[\mathrm{cm}]}\end{array}$ & $\begin{array}{c}\mathrm{pH} \\
(1: 5)\end{array}$ & $\begin{array}{c}\text { EC } \\
{[\mathrm{ds} / \mathrm{m}]}\end{array}$ & $\begin{array}{c}\text { Avail-P } \\
{[\mathrm{ppm}]}\end{array}$ & $\begin{array}{c}\text { Total N } \\
{[\%]}\end{array}$ & $\begin{array}{c}\text { OM } \\
{[\%]}\end{array}$ & Soil texture \\
\hline $0-15$ & 8.4 & 0.30 & 12.8 & 0.079 & 0.77 & Clay \\
$15-30$ & 8.5 & 0.30 & 10.3 & 0.078 & 0.75 & Clay \\
$30-45$ & 8.3 & 0.32 & 7.1 & 0.076 & 0.75 & Clay \\
$45-60$ & 8.6 & 0.33 & 4.4 & 0.063 & 0.78 & Clay \\
$60-75$ & 8.3 & 0.34 & 4.2 & 0.054 & 0.63 & Clay \\
$75-90$ & 8.3 & 0.29 & 4.5 & 0.046 & 0.70 & Clay \\
\hline
\end{tabular}

EC - electrical conductivity; OM - organic matter 
In each experimental unit under all irrigation methods, $1.0 \mathrm{~m}^{2}$ labelled subplot was established at the end of the central row, and fertilised with a $2 \%$ atom excess ${ }^{15} \mathrm{~N}$-labeled urea at the same rate as the specified $\mathrm{N}$ applications.

\section{Plant sampling and analysis}

At the tuber bulking stage, two whole plant samples from the labelled subplots of all experimental units were collected. The samples were separated into two parts, tubers and aboveground vegetative part. The two parts were weighed and then oven dried at $65^{\circ} \mathrm{C}$, weighed again for dry matter yield determination (TDM), then ground and analyzed for ${ }^{15} \mathrm{~N}$ atom excess (a.e \%) and total $\mathrm{N}$ content percentage (Zapata 1990). Isotopic ${ }^{15} \mathrm{~N}$ (a.e \%) was determined by emission spectrometry using Jasco-N 150 emission spectrometer. Nitrogen use efficiency (NUE) was calculated according to Zapata (1990). Harvest index (HI) at bulking stage was calculated by dividing the tuber biomass by the whole plant bio-mass (the sum of tuber and aboveground biomass) of the collected plants from the labelled subplots of all experimental units. At harvest (mid-June for both seasons), tuber yield was determined from the yield subplot (the whole plot except the labelled subplot). Yield was sorted into marketable (MY) and non-marketable yield according to a local grade.

Water productivity and irrigation water use efficiency

Potato evapotranspiration (ETc) was calculated using the water balance equation:

$\mathrm{ETc}=1+\mathrm{P}-\mathrm{Dp}-\mathrm{Ro} \pm \Delta(\mathrm{SWC})$

where: I is the amount of irrigation water applied [mm], P is the precipitation [mm], Dp is the deep percolation [mm], and Ro is the amount of runoff [mm], $\Delta(\mathrm{SWC})$ is the change in soil water content $[\mathrm{mm}]$ in the specified soil profile. Since the amount of irrigation water was controlled, runoff was assumed to be zero. Observing SWC showed that the deep percolation was negligible below $0.60 \mathrm{~m}$ in depth. Water productivity (WP) and irrigation water use efficiency (IWUE) were calculated using equations [2] and [3], and were expressed as kg per $\mathrm{m}^{3}$ of water. WP was calculated as the relationship between fresh marketable yield (MY, t/ha) and seasonal evapotranspiration (ETc). Whereas, IWUE was calculated as the relationship between MY and the total amount of irrigation water applied $\left[\mathrm{m}^{3} / \mathrm{ha}\right]$.

$\mathrm{WP}=\frac{\mathrm{MY}}{\mathrm{ETc}}$

$\mathrm{IWUE}=\frac{\mathrm{MY}}{\mathrm{I}}$

\section{Statistical analysis}

The measured variables, i.e., fresh marketable yield (MY) at harvest, total dry matter yield (TDM) at the tuber bulking stage, water productivity (WP), irrigation water use efficiency (IWUE), nitrogen use efficiency (NUE), and harvest index (HI) were subjected to a two-way analysis of variance using the DSAASTAT add-in version 2011 (Onofri 2007). A combined analysis of data over the two studied years was performed to identify spring potato variety and irrigation methods whose average effect over years is stable and high (Gomez \& Gomez 1984). Mean comparison was made only for data after combined analysis using the least significant difference test $(L S D)$ at the $5 \%$ level of significance.

\section{RESULTS AND DISCUSSION}

\section{Marketable tuber yield (MY) and total dry matter (TDM)}

In 2010 growing season, marketable yield (MY) was affected by both tested factors (potato variety and irrigation method); while in 2011 the same trend was not observed, which might be attributed to the seasonal effect, manifested by lower average temperature and higher precipitation in 2011 compared with in 2010 (Table 1). However, the combined analysis over the two years showed no significant differences between both varieties, nor between tested irrigation methods, nor by their interaction (Tables 3 and 4).

The mean marketable yields were 27.9 and 25.8 tha, for Spunta and Marfona varieties, respectively. Although not significant, Spunta MY was $8 \%$ higher than Marfona MY, regardless of the irrigation method used. The mean MY for both potato varieties were 25.8, 26.2, 28.8, and $26.5 \mathrm{t} / \mathrm{ha}$, under drip (Drip30 and Drip60), sprinkle, and furrow irrigation 
methods, respectively. The average MY of both potato varieties under sprinkle method was $10 \%$ higher, although not significant, than MY under the other irrigation methods (Table 4). Similar results were reported which showed that the drip and furrow irrigation methods had no significant impact on tuber yield over years (Ati et al. 2012; Onder et al. 2015).

TDM at bulking stage was also not affected by either potato variety or irrigation method, in both years (Table 3). The mean TDM of Spunta variety was 10.9 t/ha which was about $11 \%$ lower, although not significant, than the mean TDM of Marfona $(12.1 \mathrm{t} / \mathrm{ha})$ regardless of the irrigation method. The mean TDMs for both potato varieties were 9.6, 11.9, 13.5, and 11.0 t/ha, under Drip30, Drip60, sprinkle, and furrow irrigation methods, respectively. Although not significant, the percentage of increase in TDM yield under sprinkle method was 28.7, 12.0, and $18.5 \%$ compared with corresponding TDM un- der Drip30, Drip60, and furrow methods, respectively (Table 4).

Regression analysis revealed that aboveground biomass and tuber yield at the bulking stage were not good parameter for estimating the fresh marketable tuber yield at harvest under both drip and furrow-irrigation methods (Table 5). This result is in agreement with the findings of Janat (2007). However, a linear regression was found to be significant under sprinkle irrigation conditions $(r=0.62$ with $p<0.05)$.

\section{Harvest index (HI)}

The combined analysis over the two years showed that the harvest index was not affected neither by the tested factors nor by their interaction (Table 3). So, no significant differences were found between both varieties, or between irrigation methods (Table 4). This finding could be explained by

$$
\mathrm{T} \text { a }
$$

Analysis of variance for marketable tuber yield (MY), total dry matter (TDM), harvest index (HI), water productivity (WP), irrigation water use efficiency (IWUE), and nitrogen use efficiency (NUE), as affected by years, varieties, and irrigation methods (significance of $F$-test values)

\begin{tabular}{|c|c|c|c|c|c|c|c|}
\hline Source of variance & $d f$ & MY & TDM & $\mathrm{HI}$ & WP & IWUE & NUE \\
\hline \multicolumn{8}{|c|}{2010} \\
\hline Irrigation methods (I) & 3 & ++ & ns & ns & ++ & ++ & ++ \\
\hline Varieties (V) & 1 & ++ & ns & ns & ++ & ++ & ns \\
\hline $\mathrm{I} \times \mathrm{V}$ & 3 & ns & ns & ns & ns & ns & ns \\
\hline Error & 8 & - & - & - & - & - & - \\
\hline \multicolumn{8}{|c|}{2011} \\
\hline Irrigation methods (I) & 3 & ns & ns & ns & ++ & ++ & ns \\
\hline Varieties (V) & 1 & ns & ns & ns & ns & ns & ns \\
\hline $\mathrm{I} \times \mathrm{V}$ & 3 & ns & ns & ns & ns & ns & ns \\
\hline Error & 8 & - & - & - & - & - & - \\
\hline \multicolumn{8}{|c|}{ Combined analysis 2010-2011 } \\
\hline Irrigation methods (I) & 3 & ns & ns & ns & ++ & ++ & ++ \\
\hline Varieties (V) & 1 & ns & ns & ns & ns & ns & ns \\
\hline \multicolumn{8}{|c|}{ Interactions } \\
\hline $\mathrm{I} \times \mathrm{V}$ & 3 & ns & ns & ns & ns & ns & ns \\
\hline Year $\times I$ & 3 & ns & ns & ns & ns & ns & ns \\
\hline Year $\times \mathrm{V}$ & 1 & ns & ns & ns & ns & ns & ns \\
\hline Year $\times \mathrm{I} \times \mathrm{V}$ & 3 & ns & ns & ns & ns & ns & ns \\
\hline Error & 16 & - & - & - & - & - & \\
\hline
\end{tabular}

${ }^{++}-$significant at $1 \%$ level; ns - non-significant at $5 \%$ level; $d f$ - degree of freedom 
the fact that MY and TDM were comparable under the different irrigation methods. Since the harvest index was calculated by dividing the tuber biomass by the whole plant biomass, and because there were no significant differences between tuber and whole plant biomass, the differences in harvest index values were very close for both potato varieties and irrigation methods. The lack of HI response might also be attributed to the uniformity of the lengths of growing season regardless of the irrigation method used, since all treatments were planted and harvested at the same time. This finding is in agreement with Janat (2007). The harvest index values reported in this study ranged between 0.71 and 0.78 , although differences were non-significant.
Water productivity and irrigation water use efficiency (WP and IWUE)

During the growing season (mid-February to mid-June), the mean values of the maximum $\left(\mathrm{T}_{\max }\right)$, minimum $\left(\mathrm{T}_{\text {min }}\right)$, overall average $\left(\mathrm{T}_{\text {average }}\right)$ temperatures, to which the plants were exposed in 2010 were, respectively, 7.0, 6.3, and 7.6\% warmer than in 2011. Concerning the relative air humidity (RH), the air was also $6.5 \%$ drier in 2010 than in 2011. Spring potato plants received a total amount of $41.7 \mathrm{~mm}$ of rain in 2010, while in 2011 they received $138.9 \mathrm{~mm}$ (Table 1). Due to the relative differences between both years concerning climatic conditions (seasonal effects), different amounts of irrigation water were applied. The irrigation water

$\mathrm{T}$ a b 1 e 4

Mean values of the marketable yield (MY) at harvest, total dry matter yield (TDM) at the tuber bulking stage, harvest index (HI), water productivity (WP), irrigation water use efficiency (IWUE), and nitrogen use efficiency (NUE) as affected by years, varieties, and irrigation methods

\begin{tabular}{|c|c|c|c|c|c|c|c|c|c|c|}
\hline \multicolumn{11}{|c|}{ Yield parameters } \\
\hline \multirow{3}{*}{$\begin{array}{l}\text { Irrigation } \\
\text { method }\end{array}$} & \multirow{3}{*}{ Variety } & \multicolumn{3}{|c|}{ MY $[\mathrm{t} / \mathrm{ha}]^{*}$} & \multicolumn{3}{|c|}{$\mathrm{TDM}[\mathrm{t} / \mathrm{ha}]^{*}$} & \multicolumn{3}{|c|}{$\mathrm{HI}^{*}$} \\
\hline & & \multicolumn{3}{|c|}{ Year } & \multicolumn{3}{|c|}{ Year } & \multicolumn{3}{|c|}{ Year } \\
\hline & & 2010 & 2011 & Av. ${ }^{* *}$ & 2010 & 2011 & Av.** & 2010 & 2011 & Av. ${ }^{* *}$ \\
\hline \multirow{2}{*}{ Drip30 } & $\mathrm{Sp}$ & 31.6 & 20.7 & \multirow{2}{*}{$25.8^{\mathrm{a}}$} & 8.1 & 9.2 & \multirow{2}{*}{$9.60^{\mathrm{a}}$} & 0.78 & 0.75 & \multirow{2}{*}{0.77} \\
\hline & $\mathrm{Ma}$ & 28.5 & 22.4 & & 12.0 & 9.0 & & 0.68 & 0.85 & \\
\hline \multirow{2}{*}{ Drip60 } & $\mathrm{Sp}$ & 32.0 & 23.8 & \multirow{2}{*}{$26.2^{\mathrm{a}}$} & 10.3 & 9.4 & \multirow{2}{*}{$11.9^{\mathrm{a}}$} & 0.75 & 0.83 & \multirow{2}{*}{0.78} \\
\hline & $\mathrm{Ma}$ & 30.7 & 18.4 & & 15.9 & 11.7 & & 0.71 & 0.84 & \\
\hline \multirow{2}{*}{ Sprinkle } & $\mathrm{Sp}$ & 36.9 & 23.3 & \multirow{2}{*}{$28.8^{\mathrm{a}}$} & 18.7 & 9.1 & \multirow{2}{*}{$13.5^{\mathrm{a}}$} & 0.69 & 0.69 & \multirow{2}{*}{0.71} \\
\hline & $\mathrm{Ma}$ & 32.2 & 22.6 & & 16.8 & 9.3 & & 0.72 & 0.74 & \\
\hline \multirow{2}{*}{ Furrow } & $\mathrm{Sp}$ & 31.1 & 23.7 & \multirow{2}{*}{$26.5^{\mathrm{a}}$} & 9.7 & 12.4 & \multirow{2}{*}{$11.0^{\mathrm{a}}$} & 0.67 & 0.84 & \multirow{2}{*}{0.78} \\
\hline & $\mathrm{Ma}$ & 28.0 & 23.3 & & 9.9 & 12.0 & & 0.77 & 0.84 & \\
\hline \multicolumn{11}{|c|}{ Water and fertiliser use parameters } \\
\hline \multirow{3}{*}{$\begin{array}{l}\text { Irrigation } \\
\text { method }\end{array}$} & \multirow{3}{*}{ Variety } & \multicolumn{3}{|c|}{$\mathrm{WP}\left[\mathrm{kg} / \mathrm{m}^{3}\right]^{*}$} & \multicolumn{3}{|c|}{ IWUE $\left[\mathrm{kg} / \mathrm{m}^{3}\right]^{*}$} & \multicolumn{3}{|c|}{ NUE $[\%]^{*}$} \\
\hline & & \multicolumn{3}{|c|}{ Year } & & Year & & & Year & \\
\hline & & 2010 & 2011 & Av. ${ }^{* *}$ & 2010 & 2011 & Av. ${ }^{* *}$ & 2010 & 2011 & Av. ${ }^{* *}$ \\
\hline Drip30 & $\mathrm{Sp}$ & 7.38 & 6.84 & $7.07^{\mathrm{a}}$ & 7.62 & 8.28 & $7.94^{\mathrm{a}}$ & 14.0 & 31.7 & $24.8^{\mathrm{b}}$ \\
\hline & $\mathrm{Ma}$ & 6.66 & 7.41 & & 6.87 & 8.97 & & 21.5 & 32.1 & \\
\hline & $\mathrm{Sp}$ & 7.48 & 7.86 & & 7.72 & 9.52 & & 17.9 & 23.9 & \\
\hline Drip60 & $\mathrm{Ma}$ & 7.17 & 6.10 & $7.15^{\mathrm{a}}$ & 7.40 & 7.38 & $8.00^{\mathrm{a}}$ & 19.8 & 31.3 & $23.2^{\circ}$ \\
\hline Sprinkle & $\mathrm{Sp}$ & 6.16 & 6.16 & $5.92^{\mathrm{b}}$ & 6.26 & 7.39 & $6.57^{\mathrm{b}}$ & 35.9 & 65.6 & $56.7^{\mathrm{a}}$ \\
\hline sprinkie & $\mathrm{Ma}$ & 5.37 & 5.99 & $5.92^{\circ}$ & 5.46 & 7.18 & 0.51 & 62.5 & 62.9 & $50.1^{\prime \prime}$ \\
\hline Furrow & $\mathrm{Sp}$ & 3.90 & 4.01 & $3.84^{\mathrm{c}}$ & 3.98 & 4.46 & $4.11^{\mathrm{c}}$ & 17.8 & 34.3 & $28.6^{\mathrm{b}}$ \\
\hline & $\mathrm{Ma}$ & 3.51 & 3.95 & & 3.58 & 4.40 & 7.11 & 26.6 & 35.6 & 20.0 \\
\hline
\end{tabular}

*Average of three replications

**Within a column, means followed by the same letter are not significantly different at $5 \%$ level according to $L S D$ test 
applied to drip, sprinkle, and furrow methods were, 4,146; 5,899; and 7,808 $\mathrm{m}^{3} / \mathrm{ha}$ in the 2010 season, and 2,$500 ; 3,147$; and $5,303 \mathrm{~m}^{3} / \mathrm{ha}$ in the 2011 season, respectively. As expected, the drip-irrigated potato crop needed less water than the other methods. The seasonal evapotranspiration (ETc), as calculated using Eq.[1], was 428, 599, and $797 \mathrm{~mm}$ under drip, sprinkle, and furrow methods conditions in the 2010 season, respectively; whereas, in the 2011 season they were 303, 377, and $591 \mathrm{~mm}$, respectively. Similar studies found that seasonal ETc for potato crop ranged from 350 to $800 \mathrm{~mm}$ under various environmental conditions (Ati et al. 2010; Badr et al. 2012; Cantore et al. 2014; Onder et al. 2015)

Analysis of variance revealed that both WP and IWUE were highly significantly influenced by both tested factors (potato variety and irrigation method) in 2010; while in $2011 \mathrm{WP}$ and IWUE were affected only by the irrigation factor. Nevertheless, the combined analysis of data over the two years confirmed that both WP and IWUE were significantly affected by the irrigation method factor at $1 \%$ level (Table 3 ). As none of the interaction effects involving irrigation methods in the combined analysis was significant at the 5\% level, the data was, therefore, averaged over the two years and both potato varieties as can be seen in Table 4 (Gomez \& Gomez 1984).

Although no significant differences were observed in marketable tuber yield between irrigation methods, both modes of drip irrigation significantly increased WP and IWUE relative to sprinkle and furrow irrigation methods. The highest values of WP and IWUE were 7.15 and $8.00 \mathrm{~kg} / \mathrm{m}^{3}$, respec-

$\mathrm{T}$ a b 1 e 5

Regression analysis of yield at harvest vs. the whole plant biomass (tuber and aboveground biomass) at the bulking stage $(r=$ coefficient of correlation)

\begin{tabular}{|l|c|}
\hline \multicolumn{1}{|c|}{$r$-values } & $\begin{array}{c}\text { Whole plant biomass at } \\
\text { the bulking stage }\end{array}$ \\
\hline Yield at harvest under Drip30 & $0.22^{\mathrm{ns}}$ \\
Yield at harvest under Drip60 & $0.51^{\mathrm{ns}}$ \\
Yield at harvest under sprinkle & $0.62^{+}$ \\
Yield at harvest under furrow & $0.39^{\mathrm{ns}}$ \\
\hline
\end{tabular}

${ }^{+}-$significant at $5 \%$ level; ${ }^{\text {ns }}$ - non-significant at $5 \%$ level tively. While the lowest values of WP and IWUE were 3.84 and $4.11 \mathrm{~kg} / \mathrm{m}^{3}$, respectively, which were obtained under furrow irrigation. The percentages of increase in WP and IWUE values under drip irrigation were about $20 \%$ compared to sprinkle, and about $95 \%$ relative to furrow irrigation. This indicates the potential of drip irrigation in saving water and improving WP and IWUE of potato crop. Onder et al. (2015) concluded that if water is in short supply, the drip irrigation method offers higher water productivity compared to the surface method. Other studies have also reported increased WP and IWUE under drip irrigation (Janat 2007; Ati et al. 2012; Badr et al. 2012; Cantore et al. 2014).

\section{Nitrogen use efficiency (NUE)}

Nitrogen use efficiency was assessed from the ${ }^{15} \mathrm{~N}$ labelled subplots for the whole plant (tubers + aboveground) at bulking stage. The combined analysis of data over the two years confirmed the main effect of irrigation methods on NUE, but none of the interactions were significant at the $5 \%$ level (Table 3). Thus, data was averaged over both years and potato varieties (Table 4). Noticeable increase in nitrogen use efficiency was observed under sprinkle-irrigated potato $(56.7 \%)$ relative to dripand furrow-irrigated potato. The value of NUE under sprinkle irrigation was as twice as those values of the other irrigation methods.

In general, NUE values under drip fertigation and furrow irrigation observed in the present study were relatively low. This could be explained by the fact that in this study NUE values were calculated up to the bulking stage only. A relatively large part of the applied nitrogen fertiliser could be recovered by the plant at a later stage due to translocation into the tubers (Westermann et al. 1988; Janat 2007; ElMokh et al. 2015). Lower NUE under drip and furrow irrigation could also be attributed to the lateral movement of ${ }^{14} \mathrm{~N}$ from its subplots to the adjacent ${ }^{15} \mathrm{~N}$ subplots and vice versa. This movement could be facilitated by water movement which is bi-dimensional under drip and furrow conditions relative to the mono-dimensional movement of water under sprinkle irrigation. On the other hand, furrow irrigation may induce $\mathrm{N}$ fertiliser leaching beyond the root zone, resulting in reduced NUE (Janat 2007). 


\section{CONCLUSIONS}

The following conclusions can be obtained from the agro-pedo-climatic context of the experiments:

- both studied factors (potato variety and irrigation method) performed consistently, and were not influenced by environmental conditions between years,

- non-significant differences were observed between the two tested spring potato varieties.

- marketable tuber and total dry matter yields were not affected by irrigation methods,

- the highest value of nitrogen use efficiency was obtained in sprinkle-irrigated potato relative to drip- and furrow-irrigated ones,

- Seasonal evapotranspiration was considerably reduced and water productivity and irrigation water use efficiency were significantly enhanced under drip-irrigated potato crop, relative to the other irrigation methods. So, adopting drip irrigation can effectively address water shortage and its consequences, for sustainable potato crop production, in the dry Mediterranean region.

Acknowledgements. The authors would like to thank the Atomic Energy Commission of Syria for the financial support.

\section{REFERENCES}

ANNUAL AGRICULTURAL STATISTICS FOR THE 2011 GROWING SEASON. Ministry of Agriculture and Agrarian Reform. Planning and Statistic Directorate, Damascus, Syrian Arab Republic.

ATI, A.S. - IYADA, A.D. - NAJIM, S.M. 2012. Water use efficiency of potato (Solanum tuberosum L.) under different irrigation methods and potassium fertilizer rates. In Annals of Agricultural Science, vol. 57, no. 2, pp. 99-103.
BADR, M.A. - EL-TOHAMY, W.A. - ZAGHLOUL, A.M. 2012. Yield and water use efficiency of potato grown under different irrigation and nitrogen levels in an arid region. In Agricultural Water Management, vol. 110, pp. 9-15.

CANTORE, V. - WASSAR, F. - YAMAC, S.S. - SELLAMI, M.H. - ALBRIZIO, R. - STELLACCI, A.M. - TODOROVIC, M. 2014. Yield and water use efficiency of early potato grown under different irrigation regimes. In International Journal of Plant Production, vol. 8, no. 3, pp. 409-428.

EL-MOKH, F. - NAGAZ, K. - MASMOUDI, M.M. - BEN MECHLIA, N. 2015. Yield and water productivity of drip-Irrigated potato under different nitrogen levels and irrigation regime with saline water in arid Tunisia. In American Journal of Plant Sciences, vol. 6, pp. 501-510.

ESKANDARI, A. - KHAZAIE, H.R. - NEZAMI, A. - KAFI, M. - MAJDABADI, A. - SOUFIZADEH, S. 2013. Effects of drip irrigation regimes on potato tuber yield and quality. In Archives of Agronomy and Soil Science, vol. 59, no. 6, pp. 889-897.

FAO. FAOSTAT. Agriculture. Rome, 2014. Available at: http:// faostat.fao.org/faostat/collections?subset=agriculture.

GOMEZ, K.A. - GOMEZ, A.A. 1984. Statistical Procedures for Agricultural Research, second ed. Wiley, New York, NY, $680 \mathrm{p}$.

JANAT, M. 2007. Efficiency of nitrogen fertilizer for potato under fertigation utilizing a nitrogen tracer technique. Commun. In Communications in Soil Science and Plant Analysis, vol. 38 , no. $17-18$, pp. 2401-2422.

ONDER, D. - ONDER, S. - CALISKAN, M.E. - CALISKAN, S. 2015. Influence of different irrigation methods and irrigation levels on water use efficiency, yield, and yield attributes of sweet potatoes. In Fresenius Environmental Bulletin, vol. 24, no. 10, pp. 3398-3403.

ONOFRI, A. 2007. Routine statistical analyses of field experiments by using an Excel extension. In La statistica nelle scienze della vita e dell'ambiente : Proceedings $6^{\text {th }}$ National Conference Italian Biometric Society, Pisa, 20-22 June, pp. 93-96.

MATOVIC, G. - BROCIC, Z. - DJURICIN, S. - GREGORIC, E. - BODROZA, D. 2016. Profitability assessment of potato production applying different irrigation methods. In Irrigation and Drainage, vol. 65, no. 4, pp. 502-513.

TIERCELIN, J.R. 2007. Traité d'irrigation. Lavoisier Tec\&Doc Edition, 1262 pp.

WESTERMANN, T.D. - KLEINKOPF, G.E. - PORTER, L.K. 1988. Nitrogen fertilizer efficiencies on potatoes. In American Potato Journal, vol. 65, pp. 377-386.

ZAPATA, F. 1990. Isotope Technique in Soil Fertility and Plant Nutrition. In HARDERSON, G. (Ed.) The Use of Nuclear Techniques in Studies of Soil-plant Relationships, IAEA publications, series no. 2, pp. 61-128.

Received: December 10, 2017 